\title{
Features of fish breeding in water with electrochemical redox potential
}

\author{
Anna Bakhareva ${ }^{1}$, Yulia Grozesku $^{1}$, Adelya Zhandalgarova ${ }^{1, *}$ Yulia Sergeeva $^{1}$, and Alexey \\ Mazlov $^{2}$ \\ ${ }^{1}$ Astrakhan State Technical University, st. Tatishcheva, 16, 414056 Astrakhan, Russia \\ ${ }^{2}$ Astrakhan State Medical University, st. Bakinskaya, 121, 414000 Astrakhan, Russia
}

\begin{abstract}
One of the most significant factors in regulating the parameters of redox reactions occurring in any liquid medium is the electron activity or redox potential (RP) of this medium. Water that has a negative RP is easily absorbed by the body and replenishes the cells with lost negative charges and energy. As a result of the conducted studies, it was found that the hydrochemical parameters in the experimental and control variants were within the standard values for growing tilapia juveniles. It was found that the redox potential of the blood of juvenile tilapia has a negative value of $96 \mathrm{mV}$. It is recorded that at a sufficiently low water temperature for thermophilic tilapia $\left(21^{\circ} \mathrm{C}\right)$ and at a negative $\mathrm{RP}(-212 \mathrm{mV})$, a high growth rate of fish is observed. It was found that the use of water with a redox potential of $-100 \mathrm{mV}$ is the most effective, since the linear weight gain of juveniles increases by $41 \%$ in comparison with the control. Tilapia juveniles grown in structured water have the highest levels of hemoglobin $(62-64 \mathrm{~g} / \mathrm{l})$ and total serum protein $(13.3-14.3 \mathrm{~g} / 1)$.
\end{abstract}

\section{Introduction}

One of the promising directions for improving water quality is its structuring [1-3]. It is known that water with a cluster structure has an improved quality in terms of both organoleptic properties and the ratio of mineral components, which contributes to the maintenance of homeostasis in the body [4-7].

Water fills all the space inside the cells and between the cells. Being the main fluid in the body, it serves as a solvent for nutrients, acts as a medium for the safe elimination of toxins and waste products, determines the quality of blood, and affects redox processes $[2,8,9]$. Water, which has a negative redox potential, is an excellent stimulant, restores the immune system of the body, provides its antioxidant protection, and also improves metabolism [10$15]$.

The technology of water activation was carried out in the past and continues to be improved at the present time. The use of active water in fish farming can greatly improve the quality of commercial products and minimize the time of cultivation.

\footnotetext{
*Corresponding author: zhandalgarova@mail.ru
} 
In this regard, the purpose of the research was to evaluate the effectiveness of growing fish in water with an electrochemically regulated redox potential.

\section{Material and research methods}

Experimental work was carried out on the basis of the Innovation center "Bioaquapark-STC of aquaculture" FSBHU HE ASTU.

Juvenile tilapia of different weight were used as objects of research. Fish cultivation was carried out in fiberglass tanks with rounded corners with a volume of $0.8 \mathrm{~m}^{3}$ with a constant flow rate. The stocking density of tilapia juveniles was determined depending on the weight of the fish grown.

The studied objects were divided into 2 groups: experimental and control. In the experimental group, the juveniles were grown in structured water, and in the control group under the standard regime. To change the redox potential (RP) of the water environment, we used water filter and activation systems developed by «Aqualid» LLC (Fig. 1).

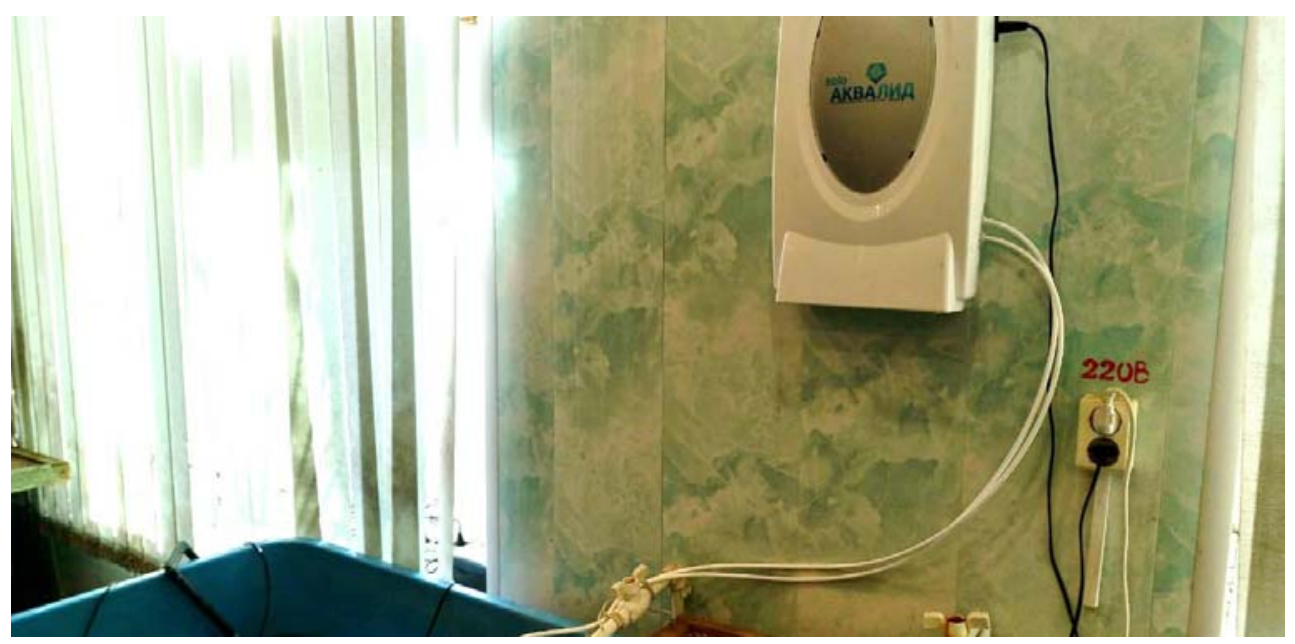

Fig. 1. «Aqualid solo» water electroactivation system

During the entire research period, observations were made on the thermal and hydrochemical regimes, water exchange, growth and development of fish. Temperature, oxygen, and $\mathrm{pH}$ were measured three times a day. For this purpose, special devices were used: a CyberScan DO 300 thermooxymeter and a HANNA pH meter. The concentrations of nitrates and nitrites were measured daily with the help of TETRA drip tests (Fig. 2). The RP of water and blood was measured using an RP meter that reflects the level of electron activity in the processes of liquid oxidation and reduction. 


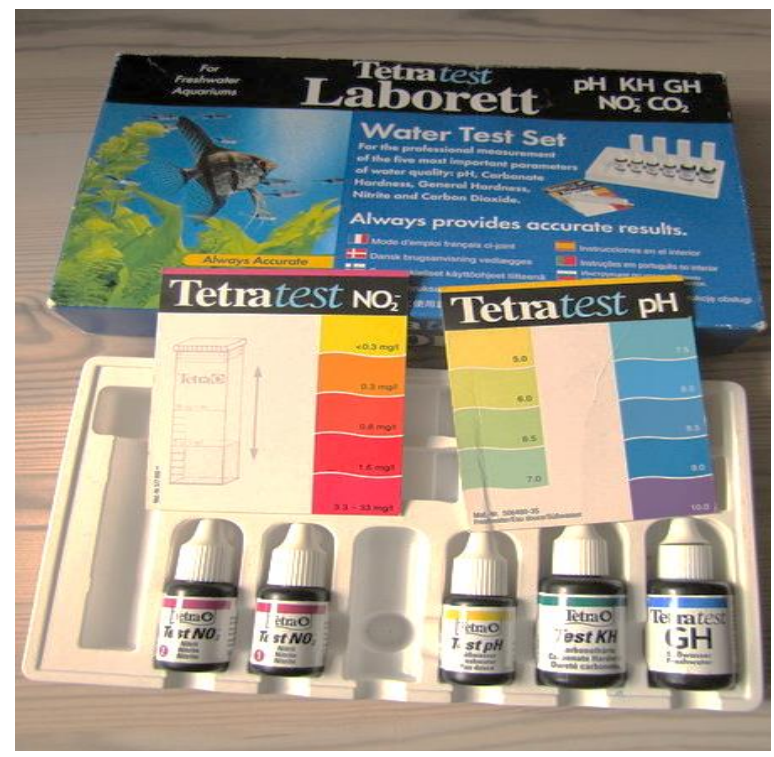

Fig. 2. Tetra drip tests

For hematological studies, blood from juvenile tilapia was collected by cutting off the caudal stem. The hemoglobin level was determined by the cyangemoglobin method, for which $5 \mathrm{ml}$ of the transforming solution was added to the test tubes, then $0.02 \mathrm{ml}$ of blood was added, thoroughly mixed and incubated at room temperature for 20 minutes. After that, the optical density of the experimental samples was measured against the blank sample (transforming solution) at a wavelength of $540 \mathrm{~nm}$ in a cuvette with a light-absorbing layer thickness of $10 \mathrm{~mm}$. To determine the level of total protein, serum was obtained, for this purpose, the selected blood was transfused into clean, dry test tubes. After the blood clotted, the clot was separated from the walls of the test tube with a needle by tracing. The serum was sucked into clean test tubes with a syringe. The protein in the serum was determined using the IRF-454B2M refractometer.

Feeding was carried out manually daily 3 times a day with mixed feed Coppens START PREMIUM. The daily feeding rate was determined depending on the body weight of the fish and the water temperature, in accordance with the generally accepted cultivation technology. Weighing and measurements were carried out according to the recommendation of Pravdin I. F.

Statistical processing of the research results was carried out according to the generally accepted methods of mathematical processing using the Microsoft Excel program. The elements of statistical analysis were used to determine the average error.

\section{Research results}

It is known that the growth rate of fish is significantly influenced by the growing conditions, such as: gas and thermal conditions, illumination, quality and availability of feed, and their balance.

When growing tilapia juveniles, it was found that an increase in weight gain is possible not only when using high-quality feed, but also when changing the structure of water. Natural water has a positive redox potential, while the internal environment of the body has a negative one. 
The conducted studies on the redox potential of the blood of juvenile tilapia showed that the RP has a negative value- $96 \mathrm{mV}$. In this regard, additional experimental work was carried out to determine the effect of the level of RP of the aquatic environment on the growth of juveniles.

During the experiment, the water temperature, as well as the content of oxygen dissolved in water and other indicators that affected the growth of tilapia juveniles, were set daily and are presented in Table 1.

Table 1. Hydrochemical parameters in the cultivation of juvenile tilapia

\begin{tabular}{|l|c|c|}
\hline \multirow{2}{*}{ Parameters } & \multicolumn{2}{|c|}{ Group } \\
\cline { 2 - 3 } & Experimental & Control \\
\hline $\mathrm{RP}, \mathrm{mV}$ & -212 & +155 \\
\hline $\mathrm{T},{ }^{0} \mathrm{C}$ & $21.0 \pm 0.24$ & $21.0 \pm 0.24$ \\
\hline $\mathrm{pH}$ & $7.5 \pm 0.07$ & $7.3 \pm 0.05$ \\
\hline $\mathrm{O}_{2}, \mathrm{mg} / \mathrm{l}$ & $7.5 \pm 0.13$ & $7 \pm 0.08$ \\
\hline $\mathrm{NO}_{2}, \mathrm{mg} / \mathrm{l}$ & $0.3 \pm 0.06$ & $0.5 \pm 0.08$ \\
\hline $\mathrm{NO}_{3}, \mathrm{mg} / \mathrm{l}$ & $2.5 \pm 0.8$ & $2.5 \pm 1$ \\
\hline
\end{tabular}

Throughout all the experimental work, the water temperature was $21^{\circ} \mathrm{C}$, which is lower than the optimal indicators for the growth of tilapia. The nitrite content was lower in the experimental group and amounted to $0.3 \mathrm{mg} / 1$, while in the control this indicator was 0.5 $\mathrm{mg} / \mathrm{l}$, which may be due to the quality of incoming water passing through the system of filters and electrochemical reactors, thus acquiring a negative redox potential. The active reaction of the medium was slightly alkaline and maintained a healthy environment of the juvenile tilapia. Nitrates were $2.5 \mathrm{mg} / 1$, which corresponds to the standards of GOST 287482.

Fish rearing, as a rule, takes place in water, the electron activity of which is higher than in the internal environment of the body. In this regard, part of the energy is spent on equalizing the RP, which reduces the efficiency of cultivation. The experiment showed that even at a sufficiently low water temperature for thermophilic tilapia of $21^{\circ} \mathrm{C}$ (optimal 25 $\left.27^{\circ} \mathrm{C}\right)$ and at a negative RP $(-212 \mathrm{mV})$, a high growth rate of fish is observed (Table 2).

Table 2. Fish-breeding and biological indicators of tilapia juveniles

\begin{tabular}{|l|c|c|}
\hline \multirow{2}{*}{\multicolumn{1}{|c|}{ Indicators }} & \multicolumn{2}{c|}{ Group } \\
\cline { 2 - 3 } & Experimental & Control \\
\hline Initial body weigth, $\mathrm{g}$ & $3.2 \pm 0.6$ & $2.9 \pm 0.5$ \\
\hline Final body weigth, $\mathrm{g}$ & $8.56 \pm 1.6$ & $7.03 \pm 1.5$ \\
\hline Absolute growth, $\mathrm{g}$ & 5.36 & 4.13 \\
\hline Average daily growth, $\mathrm{g}$ & 0.18 & 0.14 \\
\hline Relative growth rate, $\%$ & 91.2 & 83.2 \\
\hline The coefficient of fatness & 1.15 & 0.7 \\
\hline Feed ratio, units & 0.8 & 0.9 \\
\hline Survial rate, $\%$ & 98 & 98 \\
\hline The period of the experiment, day & 30 & 30 \\
\hline
\end{tabular}

The highest rates of growth intensity were found in tilapia juveniles grown in structured water. The increase in fish in this variant was slightly higher, and amounted to $5.36 \mathrm{~g}$, while 
in the control group this indicator was lower by $13 \%$. The coefficient of fatness of juveniles when grown in biologically active water was 1.6 times higher than in the control version.

Thus, it can be concluded that structured water promotes rapid digestion of food, as well as more efficient absorption of nutrients. Feed costs for fish weight gain in the experimental version were 0.1 units lower than in the control version.

The next experimental cultivation was carried out in the optimal temperature regime for tilapia growth of $25-27^{\circ} \mathrm{C}$, while the RP was brought closer to the level of the internal environment of the body. In the control version, water was supplied from the ultrasound system. The hydrochemical parameters of the medium are presented in Table 3.

Table 3. Hydrochemical parameters of water with modified RP

\begin{tabular}{|l|c|c|c|}
\hline \multirow{2}{*}{\multicolumn{1}{|c|}{ Indicators }} & \multicolumn{3}{c|}{ Group } \\
\cline { 2 - 4 } & Experimental 1 & Experimental 2 & Control \\
\hline $\mathrm{RP}, \mathrm{mV}$ & -100 & -160 & +440 \\
\hline $\mathrm{T},{ }^{0} \mathrm{C}$ & $26.0 \pm 0.24$ & $26.0 \pm 0.25$ & $26.0 \pm 0.27$ \\
\hline $\mathrm{pH}$ & $7.5 \pm 0.03$ & $7.5 \pm 0.04$ & $7.0 \pm 0.03$ \\
\hline $\mathrm{O}_{2}, \mathrm{mg} / \mathrm{l}$ & $7.5 \pm 0.13$ & $7.2 \pm 0.14$ & $6.9 \pm 0.08$ \\
\hline $\mathrm{NO}_{2}, \mathrm{mg} / 1$ & $0.2 \pm 0.05$ & $0.2 \pm 0.05$ & $0.5 \pm 0.02$ \\
\hline $\mathrm{NO}_{3}, \mathrm{mg} / \mathrm{l}$ & $2.5 \pm 0.2$ & $2.5 \pm 0.2$ & $2.5 \pm 0.3$ \\
\hline
\end{tabular}

During the study period, the average water temperature was $26^{\circ} \mathrm{C}$, with short-term differences up to $27^{\circ} \mathrm{C}$, with the optimum for tilapia-25-30 ${ }^{\circ} \mathrm{C}$. For optimal development and growth of tilapia, it is necessary to maintain an acid-base balance and the medium should be either slightly acidic or slightly alkaline in the range of 6.0-8.0 [9]. In the experimental versions, this indicator was within the normal range and its value was 7-7. 5. The concentration of oxygen dissolved in water during the experiment was stable and fluctuated within insignificant limits. On average, in the experimental and control variants, this indicator corresponded to $7 \mathrm{mg} / \mathrm{l}$.

According to the obtained hydrochemical data, it can be seen that cathode water has a number of advantages that have a positive effect on the state of the aquatic environment, as well as on the growth rate of fish and feed costs per unit of growth (Table 4).

Table 4. The results of rearing juveniles of tilapia in the water with the modified RP

\begin{tabular}{|l|c|c|c|}
\hline \multirow{2}{*}{\multicolumn{1}{|c|}{ Indicators }} & \multicolumn{3}{|c|}{ Group } \\
\cline { 2 - 4 } & $\begin{array}{c}\text { Experimental 1 } \\
\text { RP -100 }\end{array}$ & $\begin{array}{c}\text { Experimental 2 } \\
\text { RP -160 }\end{array}$ & $\begin{array}{c}\text { Control } \\
\text { RP }+440\end{array}$ \\
\hline Initial body weigth, $\mathrm{g}$ & $18.4 \pm 8.1$ & $18.6 \pm 9.3$ & $18.9 \pm 9.5$ \\
\hline Final body weigth, g & $40.4 \pm 10.5$ & $29.5 \pm 10$ & $28 \pm 9.8$ \\
\hline Absolute growth, g & 22.0 & 10.9 & 9.1 \\
\hline $\begin{array}{l}\text { Average daily growth, } \\
\text { g }\end{array}$ & 0.73 & 0.36 & 0.30 \\
\hline Relative growth rate, $\%$ & 74.8 & 45.3 & 38.8 \\
\hline $\begin{array}{l}\text { The coefficient of } \\
\text { fatness }\end{array}$ & 1.5 & 1.2 & 0.8 \\
\hline Feed ratio, units & 0.7 & 0.7 & 0.8 \\
\hline Survial rate, $\%$ & 100 & 100 & 100 \\
\hline $\begin{array}{l}\text { The period of the } \\
\text { experiment, day }\end{array}$ & 30 & 30 & 30 \\
\hline
\end{tabular}


The results of the experiment allowed us to establish the advantage of using water with a redox potential of $-100 \mathrm{mV}$. The weight gain of fish in this variant was $22 \mathrm{~g}$, which is $41 \%$ more than in the control. The growth rate of tilapia juveniles in the experimental variants was more intense.

The feed coefficient in option 1 was lower than in the control and amounted to 0.7 units. The survival rate in all variants was $100 \%$. The coefficient of fatness in the first experimental group was relatively higher than in the second and control, which may indicate a greater amount of energy in the fish body, which is spent on internal processes.

The results of tilapia cultivation at different temperatures and RP showed that even with a slight change in the electrochemical potential of the fish habitat, a high growth rate is achieved and the efficiency of cultivation increases.

Habitat conditions affect the hematological parameters of fish and cause them to change depending on the temperature, oxygen content dissolved in water, salinity, $\mathrm{pH}$, composition and amount of feed consumed. Blood, as the most labile tissue, quickly reacts to the action of various factors and leads to the restoration of balance between the body and the environment (Table 5).

Table 5. Hematological parameters of tilapia juveniles

\begin{tabular}{|l|c|c|c|}
\hline \multirow{2}{*}{\multicolumn{1}{|c|}{ Indicators }} & \multicolumn{3}{|c|}{ Group } \\
\cline { 2 - 4 } & $\begin{array}{c}\text { Experimental } \\
1\end{array}$ & $\begin{array}{c}\text { Experimental } \\
2\end{array}$ & Control \\
\hline Hemoglobin, g/l & $64 \pm 0.20$ & $62 \pm 0.32$ & $60 \pm 0.34$ \\
\hline Total serum protein, g/l & $14.3 \pm 0.8$ & $13.3 \pm 0.03$ & $11.5 \pm 0.08$ \\
\hline
\end{tabular}

In tilapia juveniles grown in structured water, there was a higher content of hemoglobin (62-64 g/l) and protein (13.3-14.3 g/l). A higher content of these indicators in fish of these variants indicates their good physiological condition. In the control version, these indicators were slightly lower.

Thus, according to the results of the conducted studies, it was found that the cultivation of tilapia juveniles in water with a negative recovery potential contributes to increasing the efficiency of cultivation and improving the physiological state of fish.

\section{Conclusion}

This article scientifically substantiates the effectiveness of fish rearing in water with an electrochemically regulated redox potential. In the course of the conducted studies, it was found that the use of structured water in the cultivation of juvenile tilapia contributes to the improvement of fish-breeding, biological and hematological parameters of fish. The use of water with a redox potential of $-100 \mathrm{mV}$ is the most effective, since this indicator is close to the RP of the internal environment of the body.

\section{References}

1. I.M. Piskarev, V.A. Ushkanov, N.A. Aristova, P.P. Likhachev, T.S. Myslivets, Biophysics 55, 13-17 (2010) doi: 10.1134/S0006350910010033

2. J. Xie, X. Sun, Y. Pan, Y. Zhao, Food Control 23(2), 320-324 (2012) doi: 10.1016/j.foodcont.2011.07.019

3. D.R. Athayde, D.R.M. Flores, J.S. da Silva, A.L.G. Genro, M.S. Silva, B. Klein, R. Mello, A.J. Cichoski, Food Research International 1(100), 757-763 (2017) doi: 10.1016/j.foodres.2017.08.009 
4. V.A. Tokar, V.G. Samoday, V.V. Novomlinsky, K.M. Reznikov, A.V. Tokar European Journal of Natural History 6, 10-14 (2015)

5. N.V. Ksenz, I.G. Sidorcov, I.V. Yudaev, M.A. Taranov, A.M. Semenikhin, V.A. Chernovolov, International Journal of Automation Technology 13(4), 539-544 (2019) doi: 10.20965/ijat.2019.p0539

6. M. Ichihara, S. Sobue, M. Ito, M. Ito, M. Hirayama, K. Ohno, Medical Gas Research 5(1), 12 (2015) doi: 10.1186/s13618-015-0035-1

7. O. Matsiyevska, Technology audit and production reserves 3(33), 34-38 (2017) doi: 10.15587 / 2312-8372.2017.93633

8. I.V. Kovalenko, P.D. Kolesnichenko, Pharmacol. Clin. Pharmacol 3(2), 29-37 (2017) doi: 10.18413/2313-8971-2017-3-2-29-37

9. M. Henry, J. Chambron, Water 5, 2094-2115 (2013) DOI: 10.3390/w5042094

10. D. Gómez-Espinosa, F.J. Cervantes-Aguilar, D. Río-García, J. Carlos, Toxins, 9(3), 104-113 (2017) doi: 10.3390/toxins9030104

11. K. Audenaert, S. Monbaliu, N. Deschuyffeleer, P. Maene, F. Vekeman, G. Haesaert, S. De Saeger, M. Eeckhout, Food Control 23, 515-521 (2012) doi: 10.1016/j.foodcont.2011.08.024

12. R.D. Ridwan, T. Tantiana, D. Setijanto, A.K. Kusuma, A.F.Putranto, Kafkas Universitesi Veteriner Fakultesi Dergisi 4, 1-6 (2019) doi: 10.9775/kvfd.2018.21284

13. K. Kasuyama, T. Tomofuji, D. Ekuni, N. Tamaki, T. Azuma, K. Irie, Y. Endo, M. Morita, Journal of Clinical Periodontology 38(12), 1085-1090 (2011) doi: 10.1111/j.1600- 051X.2011.01801.x

14. T. Frohne, J. Rinklebe, R.A. Diaz-Bone, G. Du Laing, Geoderma 160(3-4), 414-424 (2011) doi: 10.1016/j.geoderma.2010.10.012

15. F. Ingel, O. Zatsepina, A. Stekhin, G. Yakovleva, O. Savostikova, A. Alekseeva, T. Iksnova, Occup Med Health Aff 1(7), 1-7 (2013) doi: 10.4172/2329-6879.1000144 